\title{
A Qualitative Study Exploring Matters of III-being and Well-being in Norwegian Activation Policy
}

\section{Carolina Ohls}

Department of Social Work and Social Policy, Oslo and Akershus University College of Applied Sciences

E-mail: carolina.ohls@hioa.no

This article is based on a qualitative study exploring reasons for ill-being and well-being among twenty participants in a Norwegian activation programme. The Qualification Programme aims to enhance participants' overall life situations and employability by offering work training to long-term social assistance recipients, among other things. As an analytic framework for discussing ill-being and well-being, this article employs Amartya Sen's capability approach, which assesses the individual's ability to live a good life, and Martha Nussbaum's conceptualisation of that approach. The findings indicate that hardship was demonstrated in the respondents' lives: participants could not cope financially and suffered from mental and physical health problems, while shame worsened their circumstances. However, participants also showed signs of enhanced well-being as they experienced increased individual agency. The study indicated a disparity between the intended and the actual direction of change in the lives of programme participants.

Keywords: Ill-being, well-being, Norwegian activation programme, the capability approach, shame.

\section{Introduction}

Norway is usually portrayed as a wealthy welfare state, offering social protection during all stages of life. Welfare services for the unemployed include unemployment benefits for the insured and means-tested social assistance for those not covered by insurance through previous employment. In 2007, the Norwegian Qualification Program (QP), a national activation programme, was introduced to support long-term social assistance recipients to find employment and to strengthen their overall life situation (NAV, 2016). In 2014, the programme had 8,338 participants (Dalgard, 2015). The twelve-month programme, with a possible twelve-month extension, includes close follow-up and individualised solutions to enhance employability such as work placement training (NAV, 2016). QP participants are entitled to a QP benefit to provide a predictable income and enable them to plan their finances over time (Ministry of Labour and Social Affairs, 2014). Unlike social assistance, this taxable benefit grants higher coverage and is paid by the local municipality, similar to an employee's normal salary. Although researchers have found signs of increased well-being among QP participants, they also have noted issues of ill-being (ReichbornKjennerud, 2009; Schafft and Spjelkavik, 2011). Participants appear to struggle with a lack of motivation, disappointment in finding work, low self-esteem, limited social networks and an overall lack of structure in their daily lives (Schafft and Spjelkavik, 2011; Djuve 
et al., 2012). In addition, several studies have suggested that unemployment in general negatively impacts peoples' well-being and/or life satisfaction (for example, see Fryer, 1986; Halvorsen, 1999; Helliwell, 2003; Eurostat, 2015). A number of recent studies have demonstrated the inherent shame and stigma often associated with claiming welfare benefits (Pemerton et al., 2013; Walker, 2014; Baumberg, 2016), and this qualitative study among unemployed Norwegian welfare recipients contributes to that body of research.

A mismatch appears to be at work between the intended direction of change that the QP is designed to offer and the actual direction of change in participants' lives. Hence, to provide purposeful support to QP participants, we must understand what triggers both their ill-being and their well-being. Against this background, this study sought to investigate: What are the reasons for ill-being and well-being among participants in the Norwegian Qualification Programme?

The analytic framework for discussing ill-being and well-being is based on Amartya Sen's capability approach and Martha Nussbaum's conceptualisation of the approach. In brief, the capability approach assesses a person's ability to live a good life (Anand et al., 2005). Nussbaum's conceptualisation of the approach is chosen since it provides a multidimensional interpretation of well-being by investigating different aspects, such as emotions, work and educational opportunities, and health. The study draws on qualitative interviews with participants engaged in QP activities, which are organised by a publicly funded activation centre in the Oslo area.

The present study is consistent with existing literature, which calls for more in-depth examination of well-being and of the effects of poverty on well-being (Bradshaw, 2011; Taylor, 2011; Deeming, 2013). Although advanced quantitative studies have focused on well-being - such as the Human Development Report (2014) and the European Social Survey (2014) - these are not tools for studying nuanced, in-depth individual perspectives on well-being. For that purpose, a qualitative study design may be more useful. As Kvale argued: 'If you want to know how people understand their world and their life, why not talk to them' (Kvale, 1996: 1).

\section{Previous research}

A number of European studies have found that activation measures have positive effects on well-being (Strandh, 2001; Andersen, 2008). Research on the Norwegian QP has focused on the description, implementation and, to some extent, the effect of programme participation. Issues impacting participants' ill-being, such as debt or poor health, are mentioned mostly to describe the programme's target population (van der Wel et al., 2006; Djuve et al., 2012; Gubrium and Lødemel, 2014). However, some studies have reported improved feelings of well-being as a result of QP participation (Reichborn-Kjennerud, 2009; Schafft and Spjelkavik, 2011). A national evaluation based on qualitative interviews with sixty-seven QP participants concluded that the participants perceived contacts with the programme professionals as empowering, and they believed their participation would enhance their possibility of finding paid work (Schafft and Spjelkavik, 2011).

In an international study, Walker et al. (2013) explored the relationship between shame and poverty, drawing upon Sen's (1983) view that shame lies at the absolute core of poverty. The study was conducted in seven research sites in China, South Korea, India, Pakistan, Uganda, the UK and Norway. Findings showed a sense of personal failure, and, consequently, the feeling of not being valued by others triggered internalised 
shame among respondents. This internalised shame was reinforced by externalised shame, manifest in other people's words and deeds in the family, schools and officialdom. Other negative responses to poverty-related shame included depression, social withdrawal, avoidance and anger. Despite national economic and cultural differences in the sites, the study's findings corresponded with Sen's proposition.

In Norway, Walker et al. (2013) drew upon interviews with QP participants and social assistance recipients. With regard to feelings of shame, the Norwegian research indicated that QP participants experienced less shame in comparison with social assistance recipients (Gubrium and Lødemel, 2014).

Nussbaum's conceptualisation of the capability approach has been applied in a number of studies, such as that of Anand et al. (2005), who examined capabilities and well-being. Utilising data from the 2000 British Household Panel Survey (BHPS), which sampled more than 5,000 households, Anand et al. concluded that capabilities and personality traits influence feelings of well-being; however, they maintained that capabilities are more important to well-being than personality traits.

\section{Theoretical framework - the capability approach}

The capability approach assesses a person's quality of life, based on the individual's functionings and capabilities (Sen, 1993). Functionings refer to a person's 'doings' and 'beings' and may range from elementary factors - 'being adequately nourished, being in good health etc.' (Sen, 1993: 36) - to more complex ones - 'achieving self-respect, taking part in the life of the community, appearing in public without shame' (Sen, 1993: 36-7). Capabilities refer to a person's ability to achieve these functionings, and Sen argues that a person's capabilities depend on factors such as personal characteristics and social arrangements. According to Sen (1993), capabilities are an important part of individual freedom. However, he did not specify how to assign weight to different capabilities or functionings, nor did he define which functionings and capabilities are needed to live a fulfilling life because of the wide differences in context that affect each individual.

Anand et al. (2005) pointed out that functionings and capabilities are hard to distinguish when applying empirical data. For example, health and educational status are usually perceived as functionings or achievements, but they also indicate a person's capability to do certain things. In addition, other scholars have criticised the capability approach for its 'uncertainty'. For instance, Qizilbash (2008: 62) argued that the approach is 'incomplete', while Alkire (2008) pointed out that it could be viewed as a work in progress. Robyens claimed that the capability approach is: 'not a theory that can explain poverty, inequality or well-being; it rather provides a tool and a framework within which to conceptualise and evaluate these phenomena' (Robyens, 2005: 94).

Nussbaum (2011: 33-4) chose a different approach by proposing a list of central capabilities. The list includes descriptive key words: life (living to the end of human life); bodily health (having good health, adequate nourishment and adequate shelter); bodily integrity (moving freely); senses, imagination and thought (applying senses, thoughts and ideas purposefully; access to education); emotions (experiencing sound attachments, living without fear and anxiety); practical reasons (having a conception of the good, a plan for one's life); affiliation (showing concern for other people, being treated with dignity); other species (caring about animals, plants and the environment); play (living joyfully, enjoying recreational activities) and control over one's environment (granted rights such 
as political engagement and property rights). According to Nussbaum (2006), central capabilities are the requirements for a life of dignity, and the list is open-ended and may undergo modification. By defining needed capabilities, Nussbaum also developed a theory of justice with which governments should endorse capabilities (Robyens, 2005).

For this article, a modified version of Nussbaum's list was applied as an analytic version to discuss issues of ill-being and well-being among programme participants. The list leaves room for interpretation; the capabilities are rather abstract and challenging to demonstrate empirically. Because of insufficient empirical data, three of Nussbaums's capabilities - life, other species and play - were not considered. The capability labelled 'life - being able to live to the end of human life of normal length', is impossible to judge. Whether an individual will live a human life of normal length cannot usually be determined, and, therefore, was omitted from this study. The capabilities labelled other species and play also were omitted because no relevant empirical data were collected. The capability called 'bodily health' encompasses a range of aspects, such as having good health and access to nourishment and adequate shelter. For this study, the capability of bodily health was divided into two different categories, 'physical and mental health' and 'adequate housing'. The modified list of capabilities is presented and reviewed in the findings and the discussion sections.

\section{Methods}

This study utilised semi-structured, one-on-one interviews with twenty QP participants, of whom thirteen had a minority background. Literature on qualitative research suggests a range of $15 \pm 10$ respondents (see, for example, Kvale, 1996; Charmaz, 2009).

\section{Sampling strategy}

The primary sampling criteria were (1) that the participants be actively engaged in publicly funded QP activities and (2) that the sample be representative of the ethnic backgrounds of local QP participants. In the Oslo area, 70 per cent of QP participants are ethnic minorities (Ohrem-Naper, 2010). The selected research site offers publicly funded activities, including language training, work placement and motivational training, to approximately 175 QP participants each year. The majority of the site's QP participants were from an ethnic minority group and most were female.

\section{Data collection}

Seventeen participants were recruited through QP counsellors working at the centre; the researcher recruited three additional participants by directly approaching QP participants at the site. The interviews were conducted in a quiet space at the centre, which was a convention meeting spot for participants who visited the centre daily or weekly. For practical reasons, two interviews were conducted off premises, in a café and the participant's work-training site. Interviews were conducted in Norwegian using a semistructured interview guide with topics related to QP participation. Among other things, participants were asked how they perceived their QP activation, whether QP activation led to heightened feelings of shame, their previous experience of activation measures and their future aims. Although respondents shared both negative and positive experiences 
concerning QP, they also discussed personal experiences, including their personal failures and financial hardships. These experiences indicated existing issues of ill-being, and are explored further in this article.

Generally, the interviews lasted for approximately forty-five to sixty minutes, although language issues prompted some to be slightly shorter. The interviews were recorded and transcribed by the researcher. As compensation for their taking part in an interview, participants received a gift card worth NOK 100, or approximately 12 euros.

\section{Limitations}

Regular contact between QP counsellors and participants may have risked a 'creaming effect' within the sample; that is, QP counsellors may have recruited respondents whom they favoured. Due to confidentiality issues, the researcher did not have access to the participants' telephone numbers or email addresses, and, therefore, QP counsellors were needed to establish initial contact. In addition, language issues arose during the first set of interviews, and the research asked the QP counsellors to consider the potential respondents' Norwegian language skills during recruitment. Some participants from ethnic minority groups had difficulty expressing themselves in Norwegian. In hindsight, a translator should have been consulted for these cases. One female participant was interviewed twice in a seven-month period because her Norwegian had improved significantly during that time span. The latter interview was used for analytic purposes.

\section{Overview of respondents}

The interviewed respondents included thirteen women and seven men between the ages of thirty and fifty. Nine of the thirteen women were from an ethnic minority, having been born in Africa, the Middle East, South Asia or Latin America. Of the seven male respondents, four were from an ethnic minority, having been born in the Middle East and Africa. All respondents joined the QP because of unemployment and most had been engaged in other activation work courses before coming to the centre. In addition, the majority of respondents had spent six to eighteen months at the centre, most often participating in activities such as work placements and Norwegian language group training. All the ethnic Norwegians respondents had been previously employed, but among the ethnic minority participants, the men more than the women had had previous work experience.

\section{Analysis}

The researcher conducted an interpretative phenomenological analysis (IPA) of the interviews, which is an acknowledged approach especially in qualitative health and psychological studies (Biggerstaff and Thompson, 2008; Thompson et al., 2002). IPA involves examining the participant's life in detail, exploring personal experiences through the individual's perceptions or accounts of an object or an event, which are the point of departure for ascribing meaning to experiences (Smith and Osborn, 2007; Biggerstaff and Thompson, 2008). This individualised, phenomenological approach supported the intent of the research question: to explore perceptions of ill-being among QP participants.

Biggerstaff and Thompson (2008) identified four stages of IPA: a first encounter with the text, preliminary identification of themes, organising themes into clusters or concepts 
and developing a list or table of themes to identify the dominant features and concerns. These stages were used in this study with some modifications. First, the researcher read the verbatim transcripts, and coded the data using the qualitative software program, Atlas.ti. Codes were interpreted as underlying themes, such as (1) trust in staff, (2) financial difficulties and (3) housing issues. Next, the codes were clustered into groups of themes corresponding to Nussbaum's central capabilities.

\section{Findings}

Nussbaum's list of capabilities was applied with modifications to relate the findings and the capabilities purposefully to each other. The modified list was physical and mental health, adequate housing, educational opportunities, engaging in meaningful activities, being treated with dignity and the right to engage politically.

Below, the findings for each of these capabilities are presented and illustrated with extracts from the interviews.

\section{Physical and mental health}

Nearly all of the twenty participants touched upon problems related to physical and/or mental health. For three participants, physical health issues stemming from previous physically demanding work affected their ability to find employment. Their poor health restricted the type of work they could perform. The participants' mental health problems were described as depression, sleeping difficulties and anxiety. Sven shared his experiences of depression in the following way:

I struggle with showing up at my work placement. I went through a huge depression last year; it went on for a while. I guess it was due to financial problems; my past was haunting me.

For four participants with minority backgrounds, mental health issues were rooted in experiences of war in their home countries prior to coming to Norway. Joseph explained that he had taken part in the Introductory Programme, a two-year mandatory programme for those granted asylum, which includes 600 hours of Norwegian language training and work placement, among other things. However, he had not been able to focus on the programme because of anxiety caused by war experiences, and had not sought help for his traumas. He was still struggling with depressive thoughts:

If I am just spending time at home, I get depressed. I think too much ... Some days, life just gets too much for me.

Mohammed had been on sick leave for two years because of depression stemming from war experiences in his home country. He stated he had treated himself because he could not find satisfactory professional help. For Akif, war in his home country made him question what direction he should take in life:

There are a lot of problems in my home country. And I ask myself, what should I do? Everything is gone. What am I supposed to do? I do not like the killings and bombings. 


\section{Adequate housing}

Financial circumstances prevented a number of participants from finding adequate housing. For example, Ingrid found her studio apartment too small, but was having difficulty moving to a larger place:

I can't afford anything bigger. I'm looking for another place, but I notice they ask for ... a deposit and I can't afford to save up this money.

Although the welfare office had guaranteed her deposit, Ingrid could not find a landlord who would accept such a deposit, an experience she described as stigmatising. She felt trapped in her living situation and questioned her ability to move on in life.

Two Norwegian-born male participants shared the experience of having to move back in with their parents because they were unemployed and could not afford to live on their own any longer. Commenting on the experience of moving back home, Johan said:

Well, it is not that hard ... but ... it is not ideal either. I don't have issues with living there, but it's nothing I want to do forever ... as soon as I find work, I will move out.

A female participant, Asiha, said poor housing conditions made her son's respiratory problems worse, but because of her unemployment, she could not afford to move.

\section{Educational opportunities}

Education levels differed strikingly among ethnic Norwegian participants, male ethnic minority participants and female ethnic minority participants. All the ethnic Norwegians had completed compulsory school and usually vocational training or university studies. Similarly, all the ethnic minority males had completed compulsory school and three had a university degree. However, the female ethnic minorities were the most educationally disadvantaged. One participant stated that schooling was not a priority for girls in her home country. Alice was the only ethnic minority woman who had higher education. However, she had not managed to find work, which she regarded as a belittling experience:

I have studied in Norway. I have studied in other Western countries. It is not an excuse, but it is not accepted here in Norway ... It should be a positive thing, which now holds a negative meaning.

According to her, the education lost meaning when she was not able to use it. Still, the dream of new educational opportunities was a recurring theme for some participants. For example, one male participant wanted to become a bus driver, a female participant wanted to be a nurse and a third wanted to finish her university studies. However, the journey towards fulfilling these goals seemed challenging. For one, regulations prevented the participant from enrolling in an educational programme while participating in QP. If they wanted to fulfil their goals, they had to quit the programme, which was not an option for participants with restricted financial resources. 


\section{Engaging in meaningful activities}

A common theme of all interviews was the desire to find paid work. By gaining employment, respondents hoped to be able to rent better housing, to support other family members and eventually to take time off from the 'daily grind'. Participants mentioned that unemployment and a lack of money had caused them to cut down on social events. For example, Aisha had not been on a holiday for years. When she received a tax refund, she saw her chance to go for a holiday, but her plan was thwarted when the National Labour and Welfare Administration informed her that she had to use her tax refund to cover her usual expenses. Aisha said:

And I got a text message from my social worker, saying 'I notice you have received a tax refund, so with this money you need to pay for this and that'. Can you imagine? [Laughter] I was just thinking, what is it with me ... ? Everybody leaves for holiday. What kind of person am I, who cannot go?

For other respondents, paid work had an importance beyond daily expenditures. Akif was desperate to find work so he could reunite his family. Without a work contract, it was very hard for this couple to actively plan for their future in Norway, and his wife's future was dependent on his employment status:

I ... need to find a job. My wife does not have the papers. She is seeking asylum ... I need a work contract and show the papers to the UDI. [Directorate of Immigration]

Still, some respondents described improvements in their ability to plan their lives. Two ethnic minority females said that improved language skills enabled them to visit the doctor without asking their husbands to accompany them to translate. In addition, respondents said QP provided an empowering activity to fill their days, enriching their capability to plan their lives. Anne described QP participation as life changing because the programme provided treatment for her depression. She described the difference between QP and social assistance this way:

Because they [QP counsellors] know that they need to help this client to find work. But for some reason ... The welfare office has a completely different way of thinking. They think that the client only comes to get money ... They only think about that. But if they had applied the same philosophy as QP, the result would have been something completely different.

At the time of the interview, Anne was one of two respondents who had been offered employment while participating in QP, and Anne's work placement led to an employment opportunity. However, work placement training also could bring disappointment. If the initiative did not lead to employment, participants often felt used by the system.

\section{Being treated with dignity}

QP respondents also expressed positive emotions about their experiences, especially concerning the QP counsellors at the centre. The respondents described the counsellors as kind and helpful, and they trusted them and felt supported and recognised by them. The respondents, including two from ethnic minority backgrounds, also said they had 
developed friendships with ethnic Norwegians, highly valued connections that positively expanded their networks. Amina described her Norwegian friend: 'She is very friendly and she supports me a lot.' In contrast, Ingrid recalled poor experiences with the social welfare office, using phrases as 'they ruin things for you' and 'they disrespect you'. She explained:

It is much better now [while receiving QP-benefit] when you can use your own money instead of begging the social welfare office for money to pay rent and other things.

In the interviews, respondents often expressed feelings of not being worthy, which were manifest in various ways: experiencing racism on a work placement, a sense of failure due to unemployment and/or being badly treated at the welfare office. For example, Juliana, a black woman, encountered racism at her work placement at a nursery:

They are very bad. I don't know ... maybe the staff is ... I believe these people ... because of black people, immigrants ... I don't know, but it is not good ... It is racism ... I get depressed, very depressed. I don't want to be there for three months.

Two female Muslim participants gave other examples of disrespectful behaviour. One stated she had heard negative comments about her wearing a hijab from other participants at the centre. The other woman agreed that she, too, had felt pressure to conform to Norwegian clothing norms to meet her employers' wishes.

The respondents' situations that had brought them to the centre in the first place were sources of internal shame - shame for loss of status because of their unemployment, shame for seeking social assistance and shame for failing to find work. Joseph explained:

It is hard for me sometimes to go down to the NAV-office [social welfare office] and ask for food money .... It is hard for me having to rely on NAV. I don't want to.

Respondents usually lowered their voices and had difficulty talking about their feelings of shame. For example, Sven was very talkative during the interview, but when talking about shame, he became silent and struggled to express himself:

A bit of hurt feelings ... those feelings of mastery ... I believe ... I believe there is some ... shame, yes .... Absolutely [silence].

For Kari, shame was connected to external shaming and what other people would think about her:

And people think ... there is so much talk about people who are unemployed just for the sake of being unemployed, or they are on sick leave. That people choose to do these things, they do not want to work. And I am afraid that people would think the same things about me. Although I know I am not like that.

Monika also said that she had encountered people who doubted her motives; some neighbours had asked: 'Can it really be that hard to find work?' 
Most participants did not highlight political engagement as an issue. Some from minority backgrounds were not Norwegian citizens, and, thus, were ineligible vote in Norwegian elections, which, in turn, limited their capability to participate politically. However, a Norwegian-born male raised political concerns, questioning why Norway had become too focused on materialism and consumption, and an ethnic minority man mentioned that he had been imprisoned in his home country because of his political engagement.

\section{Discussion and conclusion}

Context matters, and arguably, capabilities and lack of them will differ. While lack of capabilities or signs of ill-being among welfare programme participants may not be surprising in the wider social policy context, these findings are more surprising within the smaller context of Norway, a wealthy welfare state that should be able to provide highquality services. However, as this study indicates, a high level of welfare provision may be affected by circumstances beyond the scope of welfare policies to tackle. Based on the findings of this study, some issues that seemed to elicit participants' ill-being occurred in the past or were outside the context of QP.

As shown, QP participants' physical and mental health issues may stem from past experiences. A male participant said he suffered from depression because of financial difficulties that related to prior experiences before he entered the programme. For others, earlier work experiences took a toll, causing the participants to have to turn down some jobs they could no longer perform or that may have worsened their health conditions. Previous Norwegian studies also have found that welfare recipients suffer from health issues (Wel, van der et al., 2006; Schafft and Spjeklavik, 2011).

Other examples of ill-being emerging from past experiences were evident for four of the thirteen ethnic minority respondents, all of whom had experienced war in their home countries and continued to suffer from concerns and anxiety. One such participant said he had sought help for his symptoms, but did not find it beneficial. Because of language barriers in the interviews, the reasons why other participants had not sought help were not discovered. Poor Norwegian language skills could have hindered their seeking help, as mental health interventions require sufficient language skills to verbally express one's state of mind. In addition, male participants may experience a higher threshold for seeking help than females. Still, considering the QP's goal to enhance the participants' overall well-being, this study suggests that the programme's focus should be refined to thoroughly map the participants' needs along the QP trajectory.

Furthermore, although political engagement was not a prominent issue among the respondents, the right to engage politically may be perceived as a fundamental feature of a decent society. Ethnic Norwegians may not have encountered any hindrance to their political engagement, but those who were non-citizens were ineligible to vote in parliamentary elections. This prohibition may be a double burden for those who have fled their home countries for political reasons. Although they experience safety in Norway, they may not fully participate politically until they gain Norwegian citizenship.

IIl-being stemming from shame also may have roots in participants' past experiences or situations outside the context of the programme. As Tangney and Dearing (2002) argued, shame is a painful feeling to experience, which was clear during the interviews. 
Certain situations, including financial struggles, were almost too shameful for the participants to discuss. They expressed feelings of low self-worth and shame because of their unemployment, and this internalised shame could be reinforced by externalised shame. An example is the female participant whose potential landlords refused to accept a deposit from the welfare office.

Moreover, simply seeking government support can be shame provoking, an experience that participants described with phrases like 'it ruins you' and 'they disrespect you'. These findings are consistent with other studies that have linked shame to poverty and welfare provision (Gubrium and Lødemel, 2014; Walker et al., 2013). However, participants found receiving the QP benefit less shameful than receiving social assistance, perhaps because a stigma is usually associated with the latter, which provides meanstested benefits within the structure of welfare services (Titmuss, 1968). QP represents a new tier of social assistance that seems to offer a more empowering alternative to means-tested benefits and services (Pellissery et al., 2014).

In addition, negative associations with the unemployed could emerge from the wider Norwegian social context in which unemployment is a rather marginal phenomenon. In 2013, when the interviews were conducted, the unemployment rate was 3.6 per cent (SSB, 2016). If the unemployment rate was higher and a larger proportion of the population were affected, perhaps there would be greater individual and societal acceptance and less shame associated with being unemployed.

Not all reasons for ill-being or well-being among QP participants could be blamed on the past or an outside context; some reasons were directly linked to events within the QP. For instance, the amount of the benefit the programme paid could produce illbeing. Although the benefit was higher than that provided by social assistance, it was too low to provide financial stability. QP participants encountered financial barriers to better housing, savings for needed deposits or taking a vacation. With a risk of overemphasising one capability over another, good housing conditions may be considered crucial for well-being.

In addition, programme regulations blocked some participants from improving their employability. Enhanced employment opportunities are another capability that can be linked to well-being, but participants who sought to increase their employability through additional education encountered regulations barring them from doing so. One could question the meaning of work-enhancing opportunities without the ability to gain further education. Also, although the programme offers work placement to fill gaps in the participants' work experience, participants were disappointed when work placement did not lead to paid employment. Unfortunately, some participants experienced racial discrimination at work placement sites. Programme professionals must address such incidents directly and refuse to co-operate with potential employers who engage in discriminatory behaviour.

On the other hand, the data show that participants also experienced heightened well-being as a result of the QP. In fact, a majority of participants said the QP counsellors at the centre treated them well and were both supportive and helpful. Heightened wellbeing also could be linked to programme participation that led to actual changes. For example, a female participant gained employment, after first obtaining work placement through the programme. Other female ethnic minority participants improved their language skills sufficiently to be able to attend doctor appointments without someone accompanying them. Previous studies on QP have found similar increased feelings of 
well-being associated with programme participation (Reichborn-Kjennerud, 2009; Schafft and Spjelkavik, 2011; Djuve et al., 2012).

Moreover, findings reporting heightened well-being must be seen in the context of the chosen research site. The research site in this study is notable for its initiatives to offer tailor-made language training for QP participants and strong co-operation with employers. Such initiatives are not the norm for all programme providers, and services vary among local QP centres (Schafft and Spjelkavik, 2011). For example, centres located in richer municipalities may be able to offer 'more' services and have more staff who can support the QP participants, compared to less affluent municipalities. This study was conducted in an affluent municipality, located in the Oslo area.

In conclusion, the mismatch between the QP's intended direction of change and the actual direction of change in the participants' lives could arise from what participants experienced prior to entering the programme. The past could be haunting some participants, blocking them from taking full advantage of the programme opportunities at the present time. From a policy perspective, there ought to be an increased awareness on how past issues may impact participants' programme trajectory in the present.

\section{References}

Alkire, S. (2008) 'Using the capability approach: prospective and evaluative analyses', in F. Comim, M. Qizilbash and S. Alkire (eds.), The Capability Approach: Concepts, Measures and Applications, Cambridge: Cambridge University Press, 26-49.

Anand, P., Hunter, G. and Smith, R. (2005) 'Capabilities and well-being: evidence based on the SenNussbaum approach to welfare', Social Indicators Research, 74, 9-55.

Andersen, S.H. (2008) 'The short- and long-term effects of government training on subjective well-being', European Sociological Review, 4, 451-62.

Baumberg, B. (2016) 'The stigma of claiming benefits: a quantitative study', Journal of Social Policy, 45, 181-99.

Biggerstaff, D. and Thompson, R.A. (2008) 'Interpretative phenomenological analysis (IPA): a qualitative methodology of choice in healthcare research', Qualitative Research in Psychology, 5, 173-83.

British Household Panel Survey (2000) https://www.iser.essex.ac.uk/bhps [accessed 26.08.2016].

Bradshaw, J. (ed.) (2011) The Well-Being of Children in the UK, 3rd edn, Bristol: The Policy Press.

Charmaz, K. (2009) Constructing Grounded Theory: A Practical Guide through Qualitative Analysis, California: Sage Publications.

Dalgard, B. A. (2015) 'Sambruk i kommunale og statlige ytelser [Simultaneous use of public welfare services]', SSB, Oslo, https://www.ssb.no/sosiale-forhold-og-kriminalitet/artikler-og-publikasjoner/ _attachment/249344?_ts=1518c33a2c8 [accessed 21.05.2016].

Deeming, C. (2013) 'Addressing the social determinants of subjective wellbeing: the latest challenge for social policy', Journal of Social Policy, 42, 541-65.

Djuve, A. B., Nielsen, A. R. and Strand, H. A. (2012) 'Kvalifiseringsprogrammet og sosialhjelpsutgiftene [The Qualification programme and social assistance expenditures]', Fafo, Oslo, http://www.fafo.no/ fafo/media/com_netsukii/20290.pdf [accessed 19.05.2016].

European Social Survey (2014) http://www.europeansocialsurvey.org/data/themes.html?t=wellbeing [accessed 21.05.2016].

Eurostat (2015) Quality of Life, Facts and View, Eurostat Statistical Books, http://ec.europa.eu/eurostat/ documents/3217494/6856423/KS-05-14-073-EN-N/742aee45-4085-4dac-9e2e-9ed7e9501f23

[accessed 19.05.2016].

Fryer, D. M. (1986) 'Employment, deprivation and personal agency during unemployment', Social Behaviour, 1, 3-44. 
Gubrium, K. E. and Lødemel, I. (2014) "Not good enough': social assistance and shaming in Norway", in E. K. Gubrium, S. Pellissery and I. Lødemel (eds.), The Shame of It: Global Perspectives on AntiPoverty Policies, Bristol: Policy Press, 85-110.

Halvorsen, K. (1999) 'Arbeidsløshet som Sosialt Problem [Unemployment as a social problem]', Doctoral dissertation, HiO-rapport No13, University of Oslo.

Helliwell, J. F. (2003) 'How's life? Combining individual and national variables to explain subjective well-being', Economic Modelling, 20: 331-60.

Human Development Report (2014) 'Sustaining human progress: reducing vulnerabilities and building resilience', http://www.undp.org/content/undp/en/home/librarypage/hdr/2014-human-developmentreport/ [accessed 21.05.2016].

Kvale, S. (1996) Interviews. An Introduction to Qualitative Research Interviewing, London: Sage Publications.

Ministry of Labour and Social Affairs [Arbeids- og sosialdepartementet] (2014) 'The Qualification Programme [Kvalisifiseringsprogrammet]'. http://www.regjeringen.no/nb/dep/asd/tema/velferdspolitikk/ midtspalte/kvalifiseringsprogram.html?id=575786 [accessed 20.05.2016].

Norwegian Labour and Welfare Administration [NAV] (2016) 'Kvalifiseringsprogrammet [The Qualification Programme]', https://www.nav.no/no/Person/Flere+tema/Sosiale+tjenester/Kvalifiseringsprogrammet [accessed 21.05.2016].

Nussbaum, M. (2006) Frontiers of Justice: Disability, Nationality, Species Membership, Cambridge, MA: Harvard University Press.

Nussbaum, M. (2011) Creating Capabilities: The Human Development Approach, Harvard, MA: Harvard University Press.

Ohrem-Naper, S. (2010) 'Kvalifiseringsprogrammets deltakere: hvor lang er avstanden til arbeidsmarkedet? [The participants in Qualification Programme: how far is the distance to the labour market]', Arbeid og velferd, 3,10-19.

Pellissery, S., Lødemel, I. and Gubrium, E.K. (2014) 'Shame and shaming in policy processes', in E. K. Gubrium, S. Pellissery, and I. Lødemel (eds.), The Shame of it: Global Perspectives on AntiPoverty Policies. Bristol: Policy Press, 179-98.

Pemberton, S., Sutton, E. and Fahmy, E. (2013) 'A review of the qualitative evidence relating to the experience of poverty and exclusion', Poverty and Social Exclusion in the UK (PSE), Working Paper - Methods Series No. 22.

Qizilbash, M. (2008) 'Amartya Sen's capability view: insightful sketch or distorted picture?', in F. Comim, M. Qizilbash and S. Alkire (eds.), The Capability Approach: Concepts, Measures and Applications, Cambridge: Cambridge University Press, 53-81.

Reichborn-Kjennerud, K. (2009) 'En ny mulighet: Brukernes opplevelse av Kvalifiseringsprogrammet i NAV [A new opportunity: participants' experiences of the Qualification programme]', Arbeidsforskningsinstituttet, Oslo, http://www.hioa.no/Om-HiOA/Senter-for-velferds-ogarbeidslivsforskning/AFI/Publikasjoner-AFI/En-ny-mulighet-brukernes-opplevelse-avKvalifiseringsprogrammet-i-NAV [accessed 21.05.2016].

Robyens, I. (2005) 'The capability approach: a theoretical survey', Journal of Human Development, 6, 93-114.

Schafft, A. and Spjelkavik, Ø. (2011) Evaluering av Kvalifiseringsprogrammet: Sluttrapport [Evaluation of the qualification programme: final report], Arbeidsforskningsinstituttet, Oslo, http://evalueringsportalen.no/evaluering/evaluering-av-kvalifiseringsprogrammet-sluttrapport/AFI\% 20Kvalifiseringsprogr\%202011-4.pdf/@@inline [accessed 20.05.2016].

Sen, A. (1983) 'Poor, relatively speaking', Oxford Economics Papers, 35, 153-69.

Sen, A. (1993) 'Capability and well-being', in M. C. Nussbaum and A. Sen (eds.), The Quality of Life, Oxford: Clarendon Press, 30-53.

Smith, A. J. and Osborn, M. (2007) 'Interpretative phenomenological analysis', in J. A Smith (ed.), Qualitative Psychology: A Practical Guide to Methods, 2nd edn, London: Sage, 53-80. 
SSB (2016) Labour Force Survey, Q1 2016, Oslo: Statistics Norway, https://www.ssb.no/en/arbeidog-lonn/statistikker/aku [accessed 21.05.2016].

Strandh, M. (2001) 'State intervention and mental well-being among the unemployed', Journal of Social Policy, 1, 57-80.

Tangney, J. P. and Dearing, R. L. (2002) Shame and Guilt, New York: Guildford.

Taylor, D. (2011) 'Wellbeing and welfare: a psychosocial analysis of being well and doing well enough', Journal of Social Policy, 4, 777-94.

Thompson, A. R., Kent, G. and Smith, J. A. (2002) 'Living with vitiligo: dealing with difference', British Journal of Health Psychology, 7, 213-25.

Titmuss, R. M. (1968) Commitment to Welfare, New York: Pantheon Books.

Walker, R. (2014) The Shame of Poverty, Oxford: Oxford University Press.

Walker, R., Kyomuhendo, G. B., Chase, E., Choudhry, S., Gubrium, E. K., Jo, Y. N., Lødemel, I., Mathew, L., Mwiine, A., Pellissery, S. and Ming, Y. (2013) 'Poverty in global perspective: is shame a common denominator?', Journal of Social Policy, 42, 215-33.

Wel, K. van der, Espen, D., Lødemel, I., Løyland, B., Naper, O. S. and Slagsvold, M. (2006) Funksjonsevne blant langtidsmottakere av sosialhjelp [Functional abilities among long-term recipients of social assistance], Oslo: Høgskolen i Oslo. 